\title{
Spasticity in patients with traumatic spinal cord injury: from the patients' and physicians' perspective
}

\author{
Travmatik omurilik yaralanmalı hastalarda spastisite: Hastaların ve hekimlerin perspektifinden \\ Canan Çulha, Sibel Ünsal-Delialioğlu, Pınar Egüz, Fazıl Kulaklı, Sumru Özel \\ Department of Physical Medicine and Rehabilitation, Ankara Training and Research Hospital Physical Therapy and Rehabilitation, Ankara, Turkey \\ Received / Geliş tarihi: December 2015 Accepted / Kabul tarihi: March 2016
}

\begin{abstract}
Objectives: This study aims to investigate the incidence and severity of spasticity in patients with traumatic spinal cord injury (TSCI) from the perspective of both patients and physicians.

Patients and methods: Between January 2006 and December 2010, a total of 119 TSCI patients (91 males, 28 females; mean age $34.9 \pm 13.1$ years; range 18 to 79 years) were included in the study. The patients were asked for localization of the spasticity, its beneficial and harmful effects and whether it caused pain. The patients with pain were evaluated using the visual analog scale (VAS). The physicians used the Modified Ashworth Scale (MAS) for all patients. The spasticity was also evaluated using the Penn Spasm Frequency Scale, Spasm Severity Scale, Hygiene Scale, Deep Tendon Reflexes Scale, Clonus Score, and the Plantar Stimulation Response Scale. The patients were functionally evaluated with the Barthel Index (BI) and the Functional Independence Measurement (FIM).

Results: Spasticity was reported by 42 patients (35.3\%). Based on the MAS evaluation of the physicians, 54 patients (45.4\%) had spasticity. The FIM, BI, and VAS scores of patients with spasticity were statistically significantly worse than those without spasticity. There was a statistically significant correlation between the spasticity evaluation performed by the physicians and patients $(\mathrm{r}=0.772 ; \mathrm{p}=0.001)$. We also found a significant correlation between the MASS and VAS scores $(\mathrm{r}=0.200 ; \mathrm{p}=0.029)$ and between the patient-reported spasticity and VAS scores $(\mathrm{r}=0.345 ; \mathrm{p}=0.001)$.

Conclusion: Our study results suggest that different measurement tools should be used during clinical examination to accurately evaluate the incidence and severity of spasticity in TSCI patients.
\end{abstract}

Keywords: Assessment; measurement; spasticity; spinal cord injury.

$\ddot{O Z Z}$

Amaç: Bu çalışmada travmatik omurilik yaralanmalı (TOY) hastalarda hem hasta hem de hekim perspektifinden spastisitenin görülme sıklığı ve şiddeti araştırıldı.

Hastalar ve yöntemler: Ocak 2006 - Aralık 2010 tarihleri arasında, toplam 119 TOY’li hasta (91 erkek, 28 kadın; ort. yaş $34.9 \pm 13.1$ yıl; dağılım 18-79 yıl) çalışmaya dahil edildi. Hastalara spastisitenin yeri, yararlı ve zararlı etkileri ve ağrıya neden olup olmadığı soruldu. Ağrılı hastalar Görsel Analog Ölçeği (GAÖ) ile değerlendirildi. Tüm hastalar için hekimler tarafından Modifiye Ashworth Ölçeği (MAÖ) kullanıldı. Spastisite Penn Spazm Sıklık Ölçeği, Spazm Şiddet Ölçeği, Hijyen Ölçeği, Derin Tendon Refleksleri Ölçeği, Klonus Skoru ve Plantar Stimülasyon Yanıt Ölçeği ile de değerlendirildi. Hastalar fonksiyonel açıdan Barthel İndeksi (Bİ) ve Fonksiyonel Bağımsızlık Ölçeği (FBÖ) ile değerlendirildi.

Bulgular: Spastisite, 42 hasta (\%35.3) tarafından bildirildi. Hekimlerin MAS değerlendirmesine göre, 54 hastada (\%45.4) spastisite saptandı. Spastisiteli hastaların FBÖ, Bİ ve GAÖ skoru, spastisitesi olmayanlara kıyasla, istatistiksel olarak anlamlı düzeyde daha kötüydü. Hekim ve hastalar tarafından yapılan spastisite değerlendirmesi arasında istatistiksel olarak anlamlı bir ilişki gözlendi ( $\mathrm{r}=0.772 ; \mathrm{p}=0.001)$. Ayrıca, MAST ve GAÖ skorları arasında $(\mathrm{r}=0.200 ; \mathrm{p}=0.029)$ ve hasta tarafından bildirilen spastisite ve GAÖ skorları arasında $(\mathrm{r}=0.345 ; \mathrm{p}=0.001)$ anlamlı bir ilişski bulundu.

Sonuç: Çalışma sonuçlarımız, TOY’li hastalarda spastisitenin görülme sıklığı ve şiddetinin doğru bir şekilde değerlendirilmesi için, klinik muayene sırasında farklı ölçüm araçlarının kullanılması gerektiğini göstermektedir.

Anabtar sözcükler: Değerlendirme; ölçme; spastisite; omurilik yaralanması.

Corresponding author / İletişim adresi: Canan Çulha, MD. Ankara Fizik Tedavi ve Rehabilitasyon Eğitim ve Araştırma Hastanesi, Fiziksel Tıp ve Rehabilitasyon Kliniği, 06030 Sihhiye, Ankara, Turkey. e-mail / e-posta: veyseltemizkan@yahoo.com 
Spasticity is a serious and disabling problem that poses great challenges for both patients and the clinicians. Appropriate treatment methods are needed to select new treatment approaches and develop new coping methods. ${ }^{[1]}$ The Stockholm Spinal Cord Injury Study (SSCIS) has reported spastic paresis in $60 \%$ of spinal cord injury (SCI) patients with spasticity and emphasized that it is an important problem that can be severe enough to cause pain and affect the daily life of the patients in the other $40 \%$ of this group. ${ }^{[2]}$

Spinal cord injury patients following spinal shock period can have increased phasic and tonic stretch reflexes, tendon reflexes with low threshold and large amplitude, clonus, cutaneomuscular reflex-flexor withdrawal reflex, painful or painless spontaneous extensor or flexor spasms, etc. These endanger patient positioning, bed activities, transfers, stability in wheelchairs, hygiene and protection of skin integrity. There are also limitations of daily living activities and sleep problems. ${ }^{[3-6]}$ It is also difficult for the clinician to detect and grade such a disorder and decide on which patients to treat. The quantitative measurement of spasticity is difficult and complicated. The measurements tend to be subjective. The patient's spasticity can also show daily or even hourly variation. Quantitative evaluation of spasticity is quite important when determining the treatment plan and measuring the response of the patient to medical and physical treatment. There is also no fully effective measurement method. ${ }^{[4-6]}$

The Ashworth Scale (AS) and the Modified Ashworth Scale (MAS) have been used as gold standards in the comprehensive evaluation of spasticity for half a century despite their subjectivity. ${ }^{[7]}$ Self evaluation by the patients and the sensory component in spasticity have also become the focus of attention in addition to various clinical measurements besides AS and MAS in the last $15-20$ years. ${ }^{[10,11]}$

The aim of this study was to have physicians and patients themselves assess the presence of spasticity and the distribution and its severity in traumatic spinal cord injury (TSCI) and to evaluate the relationship between these evaluations.

\section{PATIENTS AND METHODS}

We included a total of 119 TSCI patients (91 males, 28 females) who had been consecutively hospitalized at the Ankara Physical Medicine and Rehabilitation Training and Research Hospital in the study between January 2006 and December 2010. Some of these patients had been hospitalized for their first rehabilitation session while others had been hospitalized a second or third time for the treatment of developing complications. All patients gave their informed consent and the protocols were approved by the local ethics committee. The study was conducted in accordance with the principles of the Declaration of Helsinki.

The TSCI patients were evaluated as crosssectional. All patients with spasticty or without, who were cooperative, ignoring their neurological levels were included in the study. The neurological level of the injury was determined according to the American Spinal Injury Association Impairment Scale (AIS) classification following a neuromuscular system examination. ${ }^{[12]}$ The patients were classified as cervical injury (C1-C7), upper thoracic injury $\left(\mathrm{T}_{1}-\mathrm{T}_{6}\right)$, lower thoracic injury $\left(\mathrm{T}_{7}-\mathrm{T}_{12}\right)$, and lumbar injury $\left(\mathrm{L}_{1}-\mathrm{L}_{5}\right)$ according to the injury levels. They were also classified as AIS-A, B, C, or D according to injury severity.

Patients were first provided basic information on increased muscle tonus and spasticity and were then queried on their own spasticity. This inquiry included whether they had spasticity in the last week by their own evaluation, the localization where they felt the spasticity (the body, upper extremity, lower extremity or any two regions), the benefits (helping standing up, creating a feeling of animation) and harmful effects (creating limitation of daily living activities, causing pain, making it more difficult to stand up by causing spasms) (Table 1). ${ }^{[1]}$ Patients with spasticity-related pain, i.e. painful flexor and extensor spasms, were evaluated with the visual analog scale (VAS). ${ }^{[13]}$

The spasticity was also evaluated by a physician using clinical scales during the same period. The muscle groups evaluated with MAS were the hip flexors, extensors, and adductors, and the knee flexors and extensors. The elbow flexors and extensors and the wrist flexors and extensors were additionally evaluated in tetraplegic patients. The highest MAS value determined for the muscles around each joint was recorded for that joint. The Modified Ashworth Scale Sum (MASS) value was found for each case by adding the MAS values of the joints (hip, knee, elbow and wrist). ${ }^{[1]}$

The spasticity was also evaluated using various clinical scales in addition to the commonly used MAS. These were the Penn Spasm Frequency Scale (PSFS), Spasm Severity Scale (SSS), Hygiene Scale (HS), Deep Tendon Reflexes Scale (DTRS), Clonus Score (CS), and the Plantar Stimulation Response Scale (PSRS). ${ }^{[8,10,14-17]}$ The patients' functional status was evaluated with the Barthel Index (BI) and the Functional Independence Measure (FIM). ${ }^{[18,19]}$ 
Table 1. Distribution of traumatic spinal cord injury patients according to the self-evaluation of their spasticity

\begin{tabular}{lcc}
\hline & $\mathrm{n}$ & $\%$ \\
\hline Do you have any spastic symptoms? & & \\
$\quad$ No & 47 & 64.7 \\
Yes & 42 & 35.3 \\
Which part of the body your spasticity affects? & & \\
Upper extremities & 1 & 2.4 \\
Trunk & 1 & 2.4 \\
Lower extremities & 16 & 38.1 \\
Trunk and lower extremities & 23 & 54.8 \\
Upper extremities, trunk and lower extremities & 1 & 2.4 \\
Harmful effects of your spasticity & & \\
No effect & 8 & 19.0 \\
Pain & 2 & 4.8 \\
ADL limitation & 10 & 23.8 \\
Pain + ADL limitation & 18 & 42.9 \\
Difficulty in standing due to pain + & & \\
$\quad$ ADL limitation + spasm & 4 & 9.5 \\
The benefits of your spasticity & & \\
Absent & 20 & 47.6 \\
Helping standing up & 18 & 42.9 \\
Feeling animation & 4 & 9.5 \\
\hline
\end{tabular}

* These queries were performed in 42 patients with spastic symptoms; ADL: Activities of daily living.

\section{Statistical analysis}

Data analysis was performed using SPSS for Windows version 15.0 software (SPSS Inc., Chicago, IL, USA). A $p$ value $<0.05$ was considered statistically significant. Shaphiro Wilk test was used to evaluate the distribution of variables. Descriptive statistics were used for variables (continuous and categorical variables). The chi-square test was used to analyze statistically significant differences between the groups (event duration as over six months and less) according to spasticity as determined by the physician (present or absent; MAS normal or increased tonus). The chi-square test was used to analyze statistically significant differences between the complete (AIS-A) and incomplete injury (AIS-B, C, D) groups according to physiciandetermined spasticity presence (present or absent; MAS normal or increased tonus).
The Mann-Whitney $U$ tests were used to analyze statistically significant differences between the FIM, BI and VAS values of cases with physiciandetermined spasticity (present or absent; MAS normal or increased tonus). The Spearman's correlation analyses were made between the event duration and the physician-determined MASS values, and between MASS values and other clinical scales, and between MASS values and FIM, BI. The power of correlation analysis was determined to be $0.00-0.25=$ very weak, $0.26-0.49=$ weak, $0.50-0.69=$ moderate, $070-0.89=$ high, $0.90-1=$ very high. ${ }^{[20]}$

\section{RESULTS}

The mean age of the subjects was $34.87 \pm 13.12$ years and median was 33.00 ( $\min 18, \max 79)$ years and the median TSCI duration was $4.50(\min 2, \max 62)$ months. The cause of injury was fall from a height in 54 (45.4\%), traffic accident in 39 (32.7\%), motorcycle accident in seven (5.9\%), firearm injury in eight (6.7\%), being trapped under falling heavy load in nine (7.6\%), and diving in two (1.7\%) patients. The neurological injury levels of the patients were given in Table 2. The AIS classification revealed that $60.5 \%$ of the patients were AIS-A and $39.5 \%$ were AIS-B, C, D. Joint passive range of motion (PROM) limitation was present in 21 patients (17.6\%). Spasticity was also present in 12 patients from the joint PROM limitation group (57.4\%).

When queried regarding spasticity, 42 TSCI patients $(35.3 \%)$ stated they suffered from spasticity. The spasticity was most commonly felt in the trunk and lower extremity and reported in these areas in $23(54.8 \%)$ of these patients. The injury of these 23 patients was cervical in 10, lower thoracic in eight and upper thoracic in six. There were 16 patients (38.1\%) complaining of spasticity in the lower extremities only and the injury was lower thoracic in 10, upper thoracic in four and cervical in two. Spasticity was considered a problem in 35 of the 42 patients (83.3\%) who felt spasticity. The most common of these problems were

Table 2. Distribution of traumatic spinal cord injury patients according to the AIS classification

\begin{tabular}{|c|c|c|c|c|c|c|c|c|c|c|}
\hline \multirow[t]{3}{*}{ Neurologic lesion level } & \multicolumn{8}{|c|}{ American Spinal Injury Association Impairment Scale } & & \\
\hline & \multicolumn{2}{|c|}{ A } & \multicolumn{2}{|c|}{$\mathrm{B}$} & \multicolumn{2}{|c|}{$\mathrm{C}$} & \multicolumn{2}{|c|}{$\mathrm{D}$} & \multicolumn{2}{|c|}{ Total } \\
\hline & $\mathrm{n}$ & $\%$ & $\mathrm{n}$ & $\%$ & $\mathrm{n}$ & $\%$ & $\mathrm{n}$ & $\%$ & $\mathrm{n}$ & $\%$ \\
\hline Cervical & 10 & & 5 & & 6 & & 5 & & 26 & 21.8 \\
\hline Upper thoracic $\left(\mathrm{T}_{1-6}\right)$ & 16 & & 0 & & 3 & & 0 & & 19 & 16.0 \\
\hline Lower thoracic $\left(\mathrm{T}_{7-12}\right)$ & 27 & & 3 & & 10 & & 3 & & 43 & 36.1 \\
\hline Lumbar & 19 & & 3 & & 5 & & 4 & & 31 & 26.1 \\
\hline Total & 72 & 60.5 & 11 & 9.2 & 24 & 20.2 & 12 & 10.1 & 119 & 100 \\
\hline
\end{tabular}


pain and the associated limitation of daily living activities as reported by 18 patients (42.9\%). When asked about the benefits of spasticity, 20 patients (47.6\%) felt there was no benefit, 18 (42.9\%) said it helped standing up and four (9.5\%) said it felt like being animated and made them feel better (Table 1).

Our MAS evaluation revealed spasticity in various degrees in 54 patients (45.4\%). We most commonly found spasticity of hip adduction (42\%) and knee extension (39.5\%). The PSFS revealed spasticity in 62 patients (52.1\%). The SSS showed that the spasticity was moderate in 37 (31.1\%) patients and in the form of severe spastic spasms in 12 (10.1\%) subjects in the spastic group. The HS revealed that 63 (52.9\%) of the 119 patients could be catheterized easily with help and 26 (21.8) were independent as regards to hygiene.
The DTRS showed increased DTR in 49 (41.1\%) of the 119 patients. The DTR was brisker than average in $38(31.9 \%)$ and hyperactive with clonus in $11(9.2 \%)$. Clonus was present in 51 (42.9\%) of the 119 patients. The Babinski reflex was positive in 59 patients (49.6\%). The Babinski reflex was in the form of mild elevation of the knee and leg flexion following mild touch in 20 patients (16.8\%) (Table 3).

Classification of the cases according to event duration as six months or less (70 patients - 58.8\%) and over six months (49 patients - 41.2\%) revealed that spasticity as determined by the physician (present or absent; MAS normal or increased tonus) was much higher in the second group with statistical significance (Chi-square test, $d f=1, p=0.011$ ). The Spearman's correlation analysis showed a statistically significantly

Table 3. Distribution of traumatic spinal cord injury patients according to the physician's spasticity evaluation

\begin{tabular}{|c|c|c|}
\hline & $\mathrm{n}$ & $\%$ \\
\hline \multicolumn{3}{|l|}{ Penn Spasm Frequency Scale } \\
\hline 0 No spasm & 57 & 47.9 \\
\hline 1 Spasm induced only by stimulation & 10 & 8.4 \\
\hline 2 Infrequent occurring less than once per hour & 26 & 21.8 \\
\hline 3 Spontaneous spasms occurring more than once per hour & 21 & 17.6 \\
\hline 4 Spontaneous spasms occurring more than ten times per hour & 5 & 4.2 \\
\hline \multicolumn{3}{|l|}{ Spasm Severity Scale ${ }^{* *}$} \\
\hline No assessment & 57 & 47.9 \\
\hline 1 Mild & 13 & 10.9 \\
\hline 2 Moderate & 37 & 31.1 \\
\hline 3 Severe & 12 & 10.1 \\
\hline \multicolumn{3}{|l|}{ Deep Tendon Reflexes Scale } \\
\hline 0 No reflex & 41 & 34.5 \\
\hline 1 Somewhat diminished, low normal & 14 & 11.8 \\
\hline 2 Average, normal reflex & 15 & 12.6 \\
\hline 3 Brisker than average, possibly indicative of disease & 38 & 31.9 \\
\hline 4 Very brisk, hyperactive, associated with clonus & 11 & 9.2 \\
\hline \multicolumn{3}{|l|}{ Clonus score ${ }^{\star}$} \\
\hline 0 Absent & 68 & 57.1 \\
\hline 1 Unsustained & 37 & 31.1 \\
\hline 2 Sustained & 9 & 7.6 \\
\hline 3 Spontaneous/light touch provoked & 5 & 4.2 \\
\hline \multicolumn{3}{|l|}{ Plantar Stimulation Response Scale } \\
\hline 0 No visible activity/flexor response & 60 & 50.4 \\
\hline 1 Flicker of movement/extensor response & 17 & 14.3 \\
\hline 2 Slight knee and hip movement & 22 & 18.5 \\
\hline 3 Knee lifted from support & 16 & 13.4 \\
\hline 4 Movement elicited by light touch & 4 & 3.4 \\
\hline \multicolumn{3}{|l|}{ Hygiene Scale* } \\
\hline 0 Independence in self caring & 26 & 21.8 \\
\hline 1 One person can clean and catheterize patient easily & 56 & 47.1 \\
\hline 2 One person can clean patient and catheterize him/her with coping & 18 & 15.1 \\
\hline 3 One person can clean patient and catheterize him/her with severe difficulty & 4 & 3.4 \\
\hline 4 Two persons can clean patient and catheterize him/her with severe difficulty & 15 & 12.6 \\
\hline
\end{tabular}


weak correlation between the event duration and the physician-determined MASS values (Spearman's $\mathrm{r}=0.343, \mathrm{p}=0.001)$.

Classification of the cases as complete (AIS-A; 72 patients - 60.5\%) and incomplete (AIS-B, C, D; 47 patients - 39.5\%) according to AIS showed no statistically significant difference between the physician-determined spasticity presence (present or absent; MAS normal or increased tonus) between these groups (Chi-square test, $\mathrm{df}=1, \mathrm{p}=0.902$ ). There was no statistically significant correlation between the patients with incomplete and complete TSCI patients according to physician-determined MASS values (Spearman's $\mathrm{r}=0.032, \mathrm{p}=0.727$ ).

We found a statistically significant high degree of correlation between physician-determined MASS value and the patient's own spasticity evaluation (Spearman's (rho) $\mathrm{r}=0.772, \mathrm{p}=0.001$ ). There was a statistically significant very weak correlation between MASS and the VAS value queried in the patients (Spearman's $r=0.200, p=0.029)$ and a weak correlation with the statement of the patient regarding the presence of spasticity and the VAS value (Spearman's $r=0.345$, $\mathrm{p}=0.001)$.

The second highest correlation following patient evaluation with MASS values was with PSFS and SSS evaluations. (Spearman's $r=0.653 \mathrm{p}=0.001, \mathrm{r}=0.608$ $\mathrm{p}=0.001$, respectively). There was also moderate correlation between MASS values and the DTRS, CS, and PSRS (Spearman's $r=0.606 \mathrm{p}=0.001, \mathrm{r}=0.437$ $\mathrm{p}=0.001, \mathrm{r}=0.548 \mathrm{p}=0.001$, respectively).

The FIM, BI and VAS values of cases with physiciandetermined spasticity (present or absent; MAS normal or increased tonus) were statistically significantly worse than those without spasticity (Mann-Whitney $\mathrm{U}$ test, $\mathrm{Z}=-4.64, \mathrm{p}=0.001, \mathrm{Z}=-4.34, \mathrm{p}=0.001, \mathrm{Z}=-2.38$, $\mathrm{p}=0.017$, respectively, Table 4). Spearman correlation analysis showed a statistically significantly moderate negative correlation between the physician-determined MASS values and the FIM and BI (Spearman's $r=-0.491$ $\mathrm{p}=0.001, \mathrm{r}=-0.451 \mathrm{p}=0.001$, respectively). There was also a statistically significantly weak negative correlation between patient-reported spasticity presence and the FIM and BI (Spearman's $r=-0.358 \mathrm{p}=0.001, r=-0.325$ $\mathrm{p}=0.001$, respectively).

The HS was the scale that showed the highest negative correlation with FIM and BI among those used by the physician to evaluate spasticity in TSCI patients. (Spearman's $\mathrm{r}=-0.552 \mathrm{p}=0.001, \mathrm{r}=-0.547$ $\mathrm{p}=0.001$, respectively).

A statistically significant correlation was found with patient-reported spasticity and all the clinical scales used by the physician as MAS $(\mathrm{p}<0.05)$.

Twenty-four (20.2\%) of all 119 patients were using oral anti-spastic drugs.

\section{DISCUSSION}

Taking into account the aims of this study, there was a statistically significantly high level of correlation between the physicians and the patients' evaluation of spasticity. We also found a significant but low degree of correlation between MASS and VAS and between spasticity as reported by the patient and the VAS.

The quantitative measurement of spasticity is a difficult and challenging problem. This measurement is very important in determining treatment plan, measuring the response of the patient to the medical and physical treatment, and predicting prognosis. Burridge et al ${ }^{[21]}$ have emphasized that objective and clinically applicable methods are needed for spasticity measurement and that it is necessary for a clinical measurement to not only measure a single aspect of spasticity but also the other components of upper motor neuron syndrome. However, there is no fully accurate and effective measurement method yet. Ashworth Scale and MAS continue to be used as the gold standard despite their severe limitations until a new measurement method is developed. ${ }^{[9]}$ Many investigators currently feel AS and MAS have high reliability for monitoring clinical changes in spasticity and recommend the use of these scales. ${ }^{[13,22,23]}$

Table 4. The Functional Independence Measure, Barthel Index, and visual analog scale scores of patients with and without spasticity determined according to Modified Ashworth Scale

\begin{tabular}{lcccccccc}
\hline & \multicolumn{3}{c}{ Normal muscle tone $(\mathrm{n}=65)$} & & \multicolumn{3}{c}{ Spasticity $(\mathrm{n}=54)$} \\
\cline { 2 - 3 } & Mean \pm SD & Median & Min-Max & & Mean \pm SD & Median & Min-Max & $p$ \\
\hline Functional Independence Measure & $90.1 \pm 22.2$ & 90.00 & $29.00-120.00$ & & $73.1 \pm 17.0$ & 73.50 & $20.00-104.00$ & $0.001^{*}$ \\
Barthel Index & $65.6 \pm 23.3$ & 65.00 & $10.00-95.00$ & & $45.6 \pm 24.0$ & 52.50 & $5.00-90.00$ & $0.001^{*}$ \\
Visual analog scale & $3.1 \pm 3.2$ & 2.00 & $0.00-9.00$ & & $4.3 \pm 2.5$ & 5.00 & $0.00-8.00$ & $0.017^{*}$ \\
\hline
\end{tabular}

SD: Standard deviation; Min: Minimum; Max: Maximum; * Statistically significant. 
We primarily used MAS together with some other scales as the tools through which physicians evaluated spasticity in TSCI patients. We found that we were able to detect spasticity that could not be perceived, beyond that stated as present by the patients. We detected spasticity that could not be perceived by the patient in $10.1 \%$ of TSCI patients. This decreased awareness of the patients may be due to the inadequacy of describing the spasticity symptoms to the patients by the clinician.

Hsieh et al. ${ }^{[15]}$ evaluated studies that used AS, MAS, PSFS, Spinal Cord Assessment Tool for Spastic Reflexes (SCATS), VAS and the pendulum test to evaluate the spasticity of the patients in their review. They reported that the most common scales used to evaluate spasticity in SCI patients were AS, MAS, PSFS and VAS. According to them, PSFS is a clinically useful evaluation tool that also reflects the perception of the patients' own spasticity. We found spasticity in various degrees in 54 cases with MAS while it was present in 57 patients according to PSFS. There were a total of 42 patients who stated spasticity was present. When evaluating cases with PSFS and observing and querying the presence of spasm, the physician found spasticity in 15 more cases than self-reported spasticity. If we consider that PSFS also reflects patient perception as reported by Hsieh et al., ${ }^{[15]}$ the patients may be disregarding mild tonus increases and spasms. The other possibility is that we have not fully explained to the patients that the spasms are an indicator of spasticity before querying them. This may have led to fewer patients self-reporting spasticity. It is important for the clinician to evaluate spasticity as soon as possible in a TSCI case by a physical examination to observe the spasms and by querying the patient and then to provide appropriate positioning in order to prevent future contractures. It is apparent that querying the patient is not sufficient in determining the presence of spasticity and clinical scales should be used to determine which patients are at risk.

Tederko et al. ${ }^{[24]}$ evaluated the reliability of MAS, DTRS, CS and PSRS in 30 cervical CSI patients and found MAS reliability to be inadequate while DTRS, CS and PSRS were much more reliable. They report that MAS reproducibility is low in young patients and that it provides information on general muscle tonus. They also felt that MAS is not an appropriate measurement method for the evaluation of patients with contracture. They found that tendon reflexes, myoclonus and the Babinski sign on examination to be much more reliable for SCI patients. ${ }^{[24]}$ We found a moderate degree of correlation between MAS and DTR, clonus and the
Babinski sign. However, we feel that it is possible to accurately determine the presence and severity of spasticity with the above mentioned evaluations in SCI cases with contracture if it is not possible to perform MAS as suggested by Tederko et al. ${ }^{[24]}$

Priebe et al. ${ }^{[10]}$ have evaluated spasticity in SCI patients using clinical scales and reported a moderate correlation between the Ashworth score, the patellar DTR score, the ankle clonus, the Achilles DTR score, the patellar DTR score and the adductor DTR score. However, there was only weak correlation between SSS and the self-report scales of painful spasms and interference with function. In conclusion, they found weak correlation of these scales with each other and reported that each scale evaluated a different aspect of spasticity. They believe that using a single scale in SCI is inadequate to demonstrate the extensiveness and severity of the spasticity. ${ }^{[10]}$

In our study, we found a statistically significant correlation between MAS and the other clinical scales that we used to evaluate spasticity. The MAS values were also similar to the self-evaluation of the patients. The evaluations that were most accurate and most similar to MAS were PSFS and SSS. Hygiene scale was the scale that showed the highest correlation with the scales used by the physician to evaluate spasticity and it measures the activities of daily living (ADL). We can therefore say that HS shows spasticity that could cause problems with patient care. We also feel that spasticity is a multidimensional problem and that just using one or two scales to evaluate spasticity in TSCI patients cannot provide adequate information on the severity and effects of the condition. Using different scales, it is possible to evaluate the various aspects of spasticity in an individual case.

Lechner et al. ${ }^{[1]]}$ have investigated the relationship between clinical evaluation and patient self-evaluation in SCI patients with spasticity. They found a weak correlation between AS and self-rated SSS-generally and a moderate correlation between the AS and selfrated SSS-presently. There was a significant but weak correlation between VAS and AS. They concluded that clinical measurements need to be complemented with patient self-evaluation for a comprehensive evaluation of spasticity. They report that patient self-evaluation could differentiate spasticity-related muscle tonus with the sensory system-related muscle tonus. They believe this differentiation could help in the approach to the proper treatment. ${ }^{[1]}$ Fleuren et al. ${ }^{[25]}$ evaluated lower extremity spasticity in 26 motor complete SCI patients and used the VAS to determine the spasticity signs 
influencing the ADL, the activities that led to spasticity and the degree of spasticity perception. They also used the Borg scale to determine the negative effects. A moderate correlation was found between spasticity and the VAS and Borg scale. ${ }^{[25]}$ We found a very weak correlation between physician-determined MAS value and VAS and a significantly weak correlation between patient-stated spasticity and VAS. We can, therefore" conclude that the patients are able to better evaluate the muscle tonus which affects the sensory nervous system, as reported by Lechner et al. ${ }^{[1]}$

Adams and Hicks ${ }^{[26]}$ have reported that spasticity has a negative effect on the quality of life with its harmful effect on the ADL in TSCI cases. These harmful effects were defined as preventing functional walking and self-care, causing pain and fatigue, disturbing sleep, causing the development of contractures and pressure sores, leading to a negative self image, preventing rehabilitation and making the work of the carer more difficult. Despite the negative effect of spasticity on the quality of life, they also mention some beneficial effects. These are increasing stability when sitting and standing, helping some ADL and transfers, increasing muscle volume and preventing osteopenia depending on the strength of the spastic muscles, and decreasing the risk of deep venous thrombosis by increasing venous return. They have recommended considering the beneficial effects when deciding on whether to treat spasticity. ${ }^{[26]}$ BravoEsteban et al. ${ }^{[27]}$ have evaluated 66 SCI patients in the subacute and chronic stage with MAS, PSFS and the Spinal Cord Assessment Tool for Spastic reflexes (SCATS) and reported a harmful effect on ADL and walking functions. Johnson et al. ${ }^{[28]}$ evaluated the rate of considering the spasticity after SCI as a problem in the first, third and fifth years and found rates of $35 \%$, $31 \%$ and $27 \%$, respectively. Levi et al. ${ }^{[2]}$ have reported the reasons for considering spasticity a problem in $40 \%$ of the patients as ADL limitation and the resultant pain. Hsieh et al. ${ }^{[15]}$ have reported the development of spastic paralysis in $65-78 \%$ of patients following TSCI with $28-43 \%$ of these patients seeing spasticity as a problem and $43-49 \%$ receiving pharmacological treatment for spasticity.

Spasticity was reported by 42 TSCI patients that we queried accordingly in our study. Approximately half of these patients mentioned the beneficial effects and another half, at a rate a little higher than in the literature, mentioned the harmful effects, i.e. felt spasticity was a problem. Spasticity was most commonly felt in the trunk and lower extremities and the most common complaint was pain together with ADL limitation. Approximately half of the TSCI patients reporting spasticity said it helped while standing up. In contrast to other reports, $9.5 \%$ of our 42 spastic patients saw this as a sign of animation and felt better. We found in our functional evaluations as physicians that TSCI patients with spasticity and related pain showed a negative effect on ADL.

Sköld et al. ${ }^{[13]}$ reported that problematic spasticity was more common with incomplete injuries than complete injuries in their study on 354 TSCI patients. They found spasticity symptoms in $93 \%$ of AIS-A and $78 \%$ of AIS-B-D patients with cervical injury and in $72 \%$ of AIS-A and $73 \%$ of AIS-B-D patients with thoracic injury. Extensor spasticity was more commonly reported as a problem by the patients. ${ }^{[13]}$ We found lower extremity spasticity most commonly in the hip adductors and knee extensors in our TSCI patients. We found no difference regarding the presence or severity of spasticity between complete and incomplete patients. According to our study, we can also say that spasticity increases as the disorder becomes chronic in TSCI patients. We need to discuss one limitation of our study at this point. The patient group included both acute-subacute and chronic TSCI patients. We have therefore evaluated spasticity in a heterogeneous group regarding event duration.

In conclusion, not one but several scales should be used together during clinical examination to more accurately evaluate the distribution and intensity of the spasticity in TSCI patients. The clinical scales used by the physician to evaluate spasticity reveal the various aspects of spasticity, while querying the patient reveals the aspects that the physician cannot uncover. We therefore believe that querying the patient in addition to the clinical examination in studies focusing on the subject is necessary and possible spasticity should be considered especially in TSCI patients who suffering from pain.

\section{Declaration of conflicting interests}

The authors declared no conflicts of interest with respect to the authorship and/or publication of this article.

\section{Funding}

The authors received no financial support for the research and/or authorship of this article.

\section{REFERENCES}

1. Katz RT, Rymer WZ. Spastic hypertonia: mechanisms and measurement. Arch Phys Med Rehabil 1989;70:144-55. 
2. Levi R, Hultling C, Seiger A. The Stockholm Spinal Cord Injury Study: 2. Associations between clinical patient characteristics and post-acute medical problems. Paraplegia 1995;33:585-94.

3. Young RR. Spasticity: a review. Neurology 1994;44:12-20.

4. Katz RT, Dewald JPA, Schmit BD. Spasticity. In: Braddom RL, editor. Physical Medicine and Rehabilitation. 2nd ed. Philadelphia: W.B. Saunders Company; 2000. p. 592-615.

5. Özcan O, Sivrioglu S. Spastisite. In: Oguz H, Dursun E, Dursun N, editörler. Tibbi Rehabilitasyon. 1. Baskı. İstanbul: Nobel Kitapevi; 2004. s. 723-40.

6. Kirazlı Y. Spastisite ve tedavisi. In: İnme Rehabilitasyon Sempozyumu. Ankara: Gazi Üniversitesi Tıp Fakültesi; 1999. s. 49-60.

7. Ashworth B. Preliminary trial of carisoprodol in multiple sclerosis. Practitioner 1964;192:540-2.

8. Bohannon RW, Smith MB. Interrater reliability of a modified Ashworth scale of muscle spasticity. Phys Ther 1987;67:206-7.

9. Levin MF. On the nature and measurement of spasticity. Clin Neurophysiol 2005;116:1754-5.

10. Priebe MM, Sherwood AM, Thornby JI, Kharas NF, Markowski J. Clinical assessment of spasticity in spinal cord injury: a multidimensional problem. Arch Phys Med Rehabil 1996;77:713-6.

11. Lechner HE, Frotzler A, Eser P. Relationship between selfand clinically rated spasticity in spinal cord injury. Arch Phys Med Rehabil 2006;87:15-9.

12. Kirshblum SC, Waring W, Biering-Sorensen F, Burns SP, Johansen M, Schmidt-Read M, et al. Reference for the 2011 revision of the International Standards for Neurological Classification of Spinal Cord Injury. J Spinal Cord Med 2011;34:547-54.

13. Sköld C, Levi R, Seiger A. Spasticity after traumatic spinal cord injury: nature, severity, and location. Arch Phys Med Rehabil 1999;80:1548-57.

14. Penn RD, Savoy SM, Corcos D, Latash M, Gottlieb G, Parke $\mathrm{B}$, et al. Intrathecal baclofen for severe spinal spasticity. $\mathrm{N}$ Engl J Med 1989;320:1517-21.

15. Hsieh JT, Wolfe DL, Miller WC, Curt A. Spasticity outcome measures in spinal cord injury: psychometric properties and clinical utility. Spinal Cord 2008;46:86-95.

16. Snow BJ, Tsui JK, Bhatt MH, Varelas M, Hashimoto SA,
Calne DB. Treatment of spasticity with botulinum toxin: a double-blind study. Ann Neurol 1990;28:512-5.

17. Platz T, Eickhof C, Nuyens G, Vuadens P. Clinical scales for the assessment of spasticity, associated phenomena, and function: a systematic review of the literature. Disabil Rehabil 2005;27:7-18.

18. Küçükdeveci AA, Yavuzer G, Tennant A, Süldür N, Sonel B, Arasil T. Adaptation of the modified Barthel Index for use in physical medicine and rehabilitation in Turkey. Scand J Rehabil Med 2000;32:87-92.

19. Küçükdeveci AA, Yavuzer G, Elhan AH, Sonel B, Tennant A. Adaptation of the Functional Independence Measure for use in Turkey. Clin Rehabil 2001;15:311-9.

20. Akgül A. Technical Statistical Analysis of Medical Researches "SPSS Applications". 2nd ed. Ankara: Emek Ofset; 2003.

21. Burridge JH, Wood DE, Hermens HJ, Voerman GE, Johnson GR, van Wijck F, et al. Theoretical and methodological considerations in the measurement of spasticity. Disabil Rehabil 2005;27:69-80.

22. Damiano DL, Quinlivan JM, Owen BF, Payne P, Nelson KC, Abel MF. What does the Ashworth scale really measure and are instrumented measures more valid and precise? Dev Med Child Neurol 2002;44:112-8.

23. Katz RT, Rovai GP, Brait C, Rymer WZ. Objective quantification of spastic hypertonia: correlation with clinical findings. Arch Phys Med Rehabil 1992;73:339-47.

24. Tederko 1, Krasuski M, Czech J, Dargiel A, GarwackaJodzis I, Wojciechowska A. Reliability of clinical spasticity measurements in patients with cervical spinal cord injury. Ortop Traumatol Rehabil 2007;9:467-83.

25. Fleuren JF, Voerman GE, Snoek GJ, Nene AV, Rietman JS, Hermens HJ. Perception of lower limb spasticity in patients with spinal cord injury. Spinal Cord 2009;47:396-400.

26. Adams MM, Hicks AL. Spasticity after spinal cord injury. Spinal Cord 2005;43:577-86.

27. Bravo-Esteban E, Taylor J, Abián-Vicén J, Albu S, SimónMartínez C, Torricelli D, et al. Impact of specific symptoms of spasticity on voluntary lower limb muscle function, gait and daily activities during subacute and chronic spinal cord injury. NeuroRehabilitation 2013;33:531-43.

28. Johnson RL, Gerhart KA, McCray J, Menconi JC, Whiteneck GG. Secondary conditions following spinal cord injury in a population-based sample. Spinal Cord 1998;36:45-50. 